\section{DE DE GRUYTER} OPEN
Journal of Intercultural Management

Vol. 7, No. 2, June 2015, pp. 125-134

DOI 10.1515/joim-2015-0014

Barbara Marciszewska ${ }^{32}$

Gdynia Maritime University

Aleksandra Grobelna ${ }^{33}$

Gdynia Maritime University

\title{
Tourism Product as a Tool Shaping Cross-cultural Approach in Marketing
}

\begin{abstract}
One of the earlier definitions of cross-cultural management focuses on its behavioral aspects and underlines an importance of interaction of people from different cultures. "Cross-cultural management is the study of the behavior of people in organizations located in cultures and nations around the world" [Adler 1983, p. 226]. This definition is based on the description of organizational behavior within countries and cultures on one hand and of organizational behavior across countries and cultures on another. Peoples from different countries often work together in the same environment creating specific interactions but they can also built special relationships during their leisure time.

Looking at the particular subject of management from this perspective it is possible to notice that tourism products have quite big potential for creating cross-cultural interactions when services are produced in different cultures or/and consumed in different cultural context. It is mainly connected with a simultaneous production and consumption on the one hand and consumer's participation in both processes on the other hand. Tourism products posses an additional feature which creates a crosscultural dimension in both production and consumption: movement (traveling) between different cultural environments which is a source of different cultural experiences; they have to be recognized a priori to be placed on the market with the tourism product. On

\footnotetext{
32 marciszewb@wp.pl

33 aleksandra.grobelna@gmail.com
} 
the other hand tourism services have to be produced according to identified consumer expectations in different cultures.

The aim of the study is to present selected aspects of tourism products which can create cross-cultural interactions and require a special managerial marketing approach. This article discusses an impact of cultural diversity on organizational behavior in international tourism and on consumer behavior in cultural tourism with a special focus on crosscultural interactions in consumption of tourism products. This is connected with the fact that tourism products are produced and consumed by tourists in different cultures; this relationship can create specific interactions of many types.

The main research method applied is a literature review on cultural tourism and marketing.

Key words: cross-cultural interactions, cultural experience, new marketing philosophy

\section{Introduction}

Marketing evolution in the tourism sector discovers an importance of cultural differences on local, regional and global markets for an efficiency of transactions. Identifying cross-cultural interactions in the sector becomes a crucial condition for successful service exchange One of the earlier definitions of cross-cultural management focuses on its behavioral aspects and underlines an importance of interaction of people from different cultures. "Cross-cultural management is the study of the behavior of people in organizations located in cultures and nations around the world. It focuses on the description of organizational behavior within countries and cultures, on the comparison of organizational behavior across countries and cultures, and, perhaps most importantly, on the interaction of peoples from different countries working within the same organization or within the same work environment" [Adler 1983, p. 226]. Looking at the particular subject of management from this perspective, it is possible to notice that service products have a rather big potential for creating cross-cultural interactions when services are produced in different cultures or/and consumed in different cultural contexts. This is mainly connected with a simultaneous production and consumption, on the one hand, and with consumer's participation in both processes, on the other hand. Tourism products possess an additional feature which creates a cross-cultural dimension in both production and consumption: movement (traveling) between different cultural environments, which is a source of different cultural experiences; they have to be recognized a priori to be placed on the market with the tourism product. On the other hand tourism services have to be produced according to identified consumer expectations in different cultures.

The aim of the study is to present selected aspects of tourism products which can create cross-cultural interactions and require a special managerial marketing approach. This article discusses an impact of cultural diversity on organizational behavior in international tourism and on consumer behavior in cultural tourism 
with a special focus on cross-cultural interactions in consumption of tourism products.

\section{Tourism product: cultural context of its production and consumption}

Most tourism products are produced in different cultures and are offered for different consumers representing particular cultures on a global market.

Changes inside enterprises and product innovations have become a crucial condition for market development in many branches of economy, including the tourism sector. Some researchers suggest that unexpected events in the world have forced tourism companies to change their strategies for improving competitive power in the global market. According to Mulvaney et al. [2007]: "The recent recovery in business tourism after September $11^{\text {th }}[\ldots]$ has forced hotel and other types of tourism companies to critically examine operations and performance...". This stimulates new approaches of tourism enterprises to the product and process management. The dynamics of global tourism market is a factor influencing tourism managers: they have to be pro-active to predict many future processes in the market; on the one hand, this requires experience development and knowledge management, and, on the other hand, understanding of internal relationships between employees and components of tourism products [Marciszewska 2004; Marciszewska 2006]. The management process and tourism product development are connected with a necessary change inside the enterprise and can lead to product innovation. Changes in an organizational process re-shape a tourism product and intensify demand not only for itself but also for other services and goods which create tourists' experience of consumption and influences future tourists' needs. This suggests that modification of the tourism product plays an important role as a marketing tool. On the global market all the changes in a tourism product involve both producers and consumers who create a new relationship often based on different cultures.

\section{Cultural tourism product and cross-cultural context of management}

Discussions concerning the management of culture have often stressed the necessity of research into this field in relation to tourism, as both play an important role in the dynamics of the development of an individual human being and the society as a whole. "The recognition of culture as an important motivation for tourism has stimulated a significant increase in the supply of cultural attractions" [Richards 2001, p. 55]. Culture does influence tourism demand and stimulates participation in culture outside a place of living; attending different cultural attractions and events brings an opportunity to create new emotions and experiences, build new relationships and help to recognize differences in attitudes, behavior, tastes, tradition, habits. Culture within the framework of tourism can involve the customer 
in such a way as to create a memorable event and stage a positive experience, even if someone faces differences in culture. Tourists usually are keen on the culture of locals, and local people are open to tourists, even if they cannot accept their customs or particular behavior.

In the real world cultural tourism stands out as an activity based on managers' and tourists' creative approaches in which culture has been a main component of the tourism product. Creativity should, therefore, be perceived as a condition of tourists' satisfaction and a 'platform' for managers' cross-cultural interaction. Taking into account that special relationships are formed not only between managers but also between tourists and natural resources [Moscardo 2000, pp. 4-5], the crosscultural aspect has to be seen as a pre-condition of sustaining tourist attractiveness. International tourism development requires understanding differences in cultures of nationalities and their relationships with the natural environment because the culture of people behavior is a determinant of sustainable tourism.

"Creativity in the field of tourism and culture relates to an interaction between the human being (whether manager or tourist/ visitor) and 'tourism resources' and so should be analyzed by means of a complex approach which brings together consideration of, on the one hand, cultural resources, such as heritage, monuments, cultural events and cultural attractions and, on the other, the type of tourist, his/her cultural background and the experiences expected" [Marciszewska \& Marciszewski 2012, p. 52]. This statement suggests a need for recognizing tourists' motives to travel which are, in practice, factors shaping tourism demand. A marketing approach to the tourism product containing a cultural component should, therefore, consider a different cultural context of tourists' attitudes, particularly when they represent different socio-demographic groups from more than one country. Managers in tourism enterprises - in addition to the pressures of man-management and customer expectations - are required to deal with challenges and misunderstandings emanating from cross cultural differences [Marciszewska \& Marciszewski 2012]. Managers' cross cultural competency becomes a crucial condition for meeting tourists' needs and creating their positive consumption experience.

\section{Culture and cross-cultural interactions as a subject of marketing}

Culture as a social phenomenon can be understood at least in a dual sense. According to a wider understanding, culture comprises a complex of distinctive spiritual, material, intellectual and emotional features that characterize a society or social groups; it also contains modes of life, the fundamental human rights, value systems, traditions and beliefs. A narrower sense of culture refers to the particularly significant ways in which the arts help to express, formulate and define the social culture. Participation in culture is usually a component of a process creating social experience through dynamic interactions between people and tangible or 
intangible elements of cultural evidence. Tourists do not live apart from the cultural environment in which they work and rest. It is through their expressive insights as consumers in music, dance, literature, film, or theatre; their values and sensibilities of the social culture are shaped in both their place of residence and the tourist destination. Cross-cultural interactions in tourist destinations are often a source of new behaviors or attitudes; this is a reason for investigation in this field, as changing personal features often build new market segments. This suggests that cross-cultural interactions have to be a subject of marketing if tourism enterprises expect growth of demand for their tourism services and integrated products. Marketing is able to create positive relationships between local societies and tourists thus stimulating penetration of cultures.

Tourism products which base on participation in culture have initiated a new theoretical approach to tourism by creating cultural tourism. The latest definitions of the 'symbiosis' of tourism and culture express an importance of relationships between three components: tourists, local societies and cultural attractions (tangible and intangible features of cultural resources, events or arts). The definition by Marciszewska [2001, p. 217] considers cultural tourism as "that activity of persons in their tourist destination and during their travel [...] which enables them to explore or experience the different way of life of other people, reflecting the social customs, religious traditions and intellectual ideas of cultural heritage". This activity requires a special relationship with other people and, in its sense, it creates a need for crosscultural interactions, especially when foreign tourists visit a tourist destination. The above definition may suggest that cultural tourism is a form of tourism in which participants seek to become acquainted with and to experience both their own and other nations' past and present cultures. Culture in its different forms (heritage, events, arts exhibitions, performance) becomes a core product which, on the one hand, is sold by enterprises and, on the other, is consumed by tourists. As production and consumption are parallel processes in a service sector, a tourist has to interact with the producer of cultural tourism product. It is the main dimension of crosscultural interaction in international tourism and subject for marketing. Thanks to this interaction, a deep interpretation of place, history, idea, people or art is possible. In view of the fact that the cultural experience constitutes the main component of cultural tourism, an analysis of some features of marketing has been made in this article with consideration of tourists' experience. The development of cultural tourism depends on the nature of visitor's experiences in places associated with the past and/or present culture of a given community. This suggests that cultural and heritage tourism creates different experiences produced by an interaction between a tourist and a cultural attraction (e.g. a historical monument, an art exhibition, a cultural event, a tradition, an idea or a work of art). An experience created by the specific interaction between people and cultural attractions could be perceived 
as a 'product' for marketing purposes. This kind of product is difficult to form because of its very subjective nature: an experience depends on tourists' individual perception. The structure of tourists' experience in the cultural tourism model is highly fragmented in terms of lifestyle, education, occupation and consumer motivation [Marciszewska 2001, Richards 2001]. However, some characteristics could be identified:

1. flexibility and change in tourists' perception depending on the cultural background of the service producer; for instance, the same exhibition in the National Gallery in London could be perceived in a different way when it is compared with the National Museum in Gdansk;

2. perishability; namely, any unsold ticket to an exhibition represents a loss of a potential visitor experience, which may affect an enterprise's ability to compete;

3. fixed features of a tourist: every person visiting a cultural attraction potentially expects some experience; it is therefore important that a variety of communication methods (in the case of international tourism it could be based on intercultural relations) should attract a tourist to visit a cultural attraction;

4. relatively large financial investment into a modern or modified tourist product which will be able to create unique experiences.

The above characteristics highlight a very sensitive nature of a tourism product which becomes a background for a new marketing philosophy considering a cultural context of every transaction as well as consumption in the tourism sector.

In light of the above statements, the question "how is cultural experience to be sold effectively?" can be answered in a marketing approach, considering the emotional aspect of participation in culture as well as the visitor's socio-demographic profile. Managers have to be able to promote effectively customers' past and future experience as well as the source of this experience (an exhibition, a competition, a performance, visual art, an idea, design). Unfortunately, researchers underline that organizations offering culture are "...wrestling with the question of how to effectively implement current marketing concepts and techniques" [Boorsma 2002, p. 65].

A specific nature of the tourist experience as a product makes it necessary to stress that the question is not one of technique but of a new marketing concept in the world of cross-cultural tourist interactions. The basic component and the main objective of marketing should be an experience expected by tourists and created by both cultural attractions and cross-cultural interactions which shape a consumer's interpretation of the evidence.

Some authors suggest that commercial management does not propose fundamental principles and established skills which could be applied independently of the context [Beirne \& Knight 2002, pp. 75-76]. The cultural experience as a special subject of marketing management also requires its own marketing philosophy which could not only support cultural participation but also co-create 
the cultural experience of visitors who establish cross-cultural interactions with local people.

Marketing of cultural experience should give different tourists an opportunity to perceive the cultural attraction in an individual way and build different opinions and emotions on the basis of the same consumption process. Expected positive experience of tourists becomes a specific subject of promotional actions which are aimed to shape required brand of the tourism product.

\section{Do emotions shape a cultural tourism product?}

Emotions often help tourists to make decisions: to visit a cultural attraction, to travel to a culturally attractive destination, to participate in a cultural event, and finally, to buy material, a tangible cultural product, e.g. a painting, sculpture, a hand-made souvenir. Even this kind of cultural product (tangible) is a subject for reflection, and a tourist buys it thanks to and for emotions or/and experience. This means that both intangible and tangible cultural products offered to tourists require a very special emotional approach in a marketing action to attract potential consumers as "...We use our emotions to help visualize ourselves benefiting from the purchase of a particular product or service" [Williams 2003]. Emotions and experiences created by tourism products are factors stimulating future customers' decisions. This means that emotions are the very beginning of every contact with culture because they are based on and create an interaction between the visitor and cultural products (such as attractions, events and art). Buying decisions of tourists are often made on an emotional basis and managers acting on markets with a different cultural tradition, habits and educational background of potential tourists have to be selective in relation to their methods of presentation of cultural tourism products and potential experience; a selection of marketing methods should be based on differentiation according to a culturally homogenous group of visitors or tourists, but the type of a cultural product and the expected tourist's experience have to be considered.

The stimulating role of emotions in the decision-making process of clients intending to visit cultural attractions has already been described by researchers [Richards 2001; Marciszewska 2005]. This is particularly true in promoting a new cultural tourism destination which is unknown to a potential tourist, and the cultural evidence is not friendly enough. In such a situation even expected emotions (e.g. adventure) can help to make a decision about the tourist destination.

This simple example reminds of the fact that visitors make decisions based on their emotional needs and desires. What this implies for marketing activities is that promotion has to be constructed to produce emotions so as to stimulate buying decisions. When dealing with material goods it is relatively easy to persuade people of the functional value of a product. However, when dealing with culture 
it is the selling and buying of services and experience which is involved, requiring different methods of promotion and different sources of emotion. Cross-cultural interactions between tourists themselves and local people open a new dimension for promotional activities and understanding people involved. These interactions create emotions which "....reflect the spectrum of experiences tourists feel before, during and after their voyages away from home" [Gnoth et al. 2000, p. 157]. According to this approach tourism managers should create positive interactions with tourists not only in a tourist destination but also during their first contact with the agency or when they traveling. Such a holistic approach requires a specific competency and communication skills of staff in the tourism enterprise.

\section{Conclusions}

To summarize, a cultural product requires a specific marketing approach: a marketer's own emotions put in promotion can bring the product to life for the cultural visitor or tourist. Intangible features of the cultural tourism product which usually have a subjective character but do create emotions and experiences in consumption should be underlined in the promotion process. These features could be perceived by tourists as a source of expected positive experiences. Focusing on intangible features of the product during a marketing activity can help to overcome negative emotions which can be created while visiting a cultural destination and consuming the products. Tourists who participate in culture expect much more from programmers than providing cultural attractions or activities. They prefer to see something new in order to have an opportunity to rest and relax or at least to experience new things [Marciszewska 2001]. Tourists whose work is related to culture expect to have a new opportunity to tailor their own work to the demands of the employment market. This expectation is important in a context of cross-cultural interactions when new manager's experience can fill in the gap in the knowledge on cross-cultural aspects. The value of this experience and knowledge is connected with the fact that promotional techniques can be used successfully in culture and its environment if factors influencing cultural participation are known. Culture creates many unpredictable emotions, reactions, and experiences which depend on tourists' different cultural backgrounds. Consequently, operational marketing of tourist products containing cultural components requires not only specific promotional instruments but, first of all, a distinct philosophy of marketing based on knowledge concerning intercultural relationships and cultural education.

The results of research analyzing the reasons for visiting cultural attractions by Polish visitors and tourists [Marciszewska 2001, p. 223] indicate that respondents visit cultural attractions mainly to experience something new, to learn something new, or to relax. In view of the fact that more than $34 \%$ of respondents visited cultural attractions to experience new things, nearly $33 \%$ to relax and more than 
$28 \%$ to learn new things, it can be presumed that emotions and experiences are revealed in the consumption. This process shapes also a local communities' attitudes towards tourists. In this context the marketing philosophy should be more customer satisfaction-oriented than profit-oriented. A marketing process in the field of culture in a wider sense will also need to be adjusted to meet the conceptual differences between the exchange of goods, on the one hand, and services and experiences, the new "offering" [Pine\&Gilmore 1999] typical of culture, on the other. A context of cross-cultural interactions which are created between consumers and producers of tourist services is an additional aspect of this philosophy. This is an objective factor which depends on the cultural environment but influences individual attitudes and perceptions.

\section{References}

Adler N.J. (1983), Cross-cultural Management Researcb: The Ostrich and the Trend, "Academy of Management Review", Vol. 8 (2), pp. 226-232.

Bailey Ch. (2000), Audiences, Artists and the Cultural Economy: Reflecting on the Experience of Visual Arts UK, "Cultural Policy", Vol. 7(1), pp. 171-196.

Beirne M., Knight S. (2002), Principles and Consistent Management in the Arts: Lessons from British Theatre, "International Journal of Cultural Policy", Vol. 8(1), pp.75-89.

Boorsma M. (2002), Arts Marketing and the Societal Functioning of the Arts: The Case of the Subsidised Dramatic Arts in the Netherlands, "International Journal of Cultural Policy", Vol. 8(1), pp. 65-74.

Gnoth J., Zins A., Lengmueller R., Boshoff C. (2000), The Relationships Between Emotions, Mood and Motivations to Travel: Towards a Cross-Cultural Measurement of Flow [in:] Woodside A.G., Crouch G.I., Mazanec J.A., Oppermann M., Sakai M.Y. (eds), Consumer Psychology of Tourism, Hospitality and Leisure, CABI Publishing. Wallingford, pp. 155-175.

Marciszewska B. (2000), Turystyka kulturowa a rozuój spoteczno-gospodarczy, Teoria Ekonomii. Zeszyty Naukowe UG.

Marciszewska B. (2001), Consumption of Cultural Tourism in Poland [in:] G. Richards (ed.), Cultural Attractions and European Tourism, CABI Publishing. Wallingford, Oxon, pp. 215-226.

Marciszewska B. (2004), Kreowanie wied $y$ y warunkiem racjonalnego wykorzystania potencjatu turystycznego Pomorza [in:] B. Marciszewska, S. Miecznikowski (eds.), Ustugi a rožój gospodarczospoteczny, Gdansk: GTN-AWFiS, pp. 24-31.

Marciszewska B. (2006), Wspótpraca sektora turystycznego i instytucji kultury a rožoój regionu [in:] Rola turystyki w strategii i polityce rozwoju gospodarki regionalnej, Zbiór materiałów konferencyjnych, Gdansk, 14-15 września WSTiH, pp. 517-522.

Marciszewska B., Marciszewski K. (2012), Promoting tourism products via 3D graphic arts. In: New challenges for tourism promotion: tackling high competition and multimedia changes /ed. by Peter Keller, Christian Laesser-Berlin: Erich Schmidt Verl., pp. 51-68.

Mazurek-Lopacińska K. (ed.) (1999), Problemy zarzadzania sfera kultury i turystyki, WarszawaWrocław, Wyd. AE. 
Moscardo J. (2000), Cultural and Heritage Tourism: The great debates [in:] Faulkner B., Moscardo G., Laws E. (eds), Tourism in the 21st century. Lessons from experience, London \& New York. Continuum, pp. 3-17.

Mulvaney R.H., O’Neil J.W., Cleveland J.N., Crouter A.C. (2007), A Model of Work-Family Dynamics of Hotel Managers, "Annals of Tourism Research, Vol. 34 (1), pp. 66.

Pine B.J., Gilmore J.H. (1999), The Experience Economy, Boston, Harvard Business School Press.

Richards G. (2001), The Experience Industry and the Creation of Attractions [in:] G. Richards (ed.), Cultural Attractions and European Tourism, CABI Publishing. Wallingford, Oxon, pp. 55-69. 